\title{
Yeraltı Kömür Madenlerinde Meydana Gelen Büyük Maden Kazaları
}

\author{
Major Mining Accidents Occured in Underground Coal Mines
}

\author{
ilknur EROL (iD , Abdulkadir ÜRÜNVEREN
}

\begin{abstract}
ÖZET
Yeraltı kömür madenciliği iş güvenliği açısından çok tehlikeli olup büyük kazalara neden olabilmektedir. Bu çalışmada geçmişten günümüze dünyada yeraltı kömür madenlerinde meydana gelen büyük maden kazaları nedenleri ile birlikte incelenmiştir. Türkiye'de 1983-2014 yılları arasında yeraltı kömür madenlerinde meydana gelen 19 faciada toplam 944 madenci hayatını kaybetmiş ve faciaların \%78,95'i grizu patlamasından kaynaklandığı kayda geçmiştir. Türkiye'de yeraltı kömür madenlerinde 1983-2014 yılları arasında meydana gelen büyük iş kazalarındaki can kayıplarının \%63'ü, gaz patlamasından kaynaklanmıștır. Amerika ve Çin, dünyanın en büyük kömür üreten ülkelerindendir. Bu sebeple, Amerika ve Çin'de yeraltı kömür madenlerinde meydana gelen büyük kazalar da analiz edilmiștir. Amerika'da 1839-2006 yılları meydana gelen 623 faciada toplam 13883 madenci hayatını kaybetmiş, faciaların \%81,1'inin grizu patlamasından, \%0,3'ünün kömür tozu patlamasından dolayı meydana gelmiştir. Çin'de 1942-2016 yılları arasında meydana gelen 189 faciada toplam 13075 kişi hayatını kaybetmiş ve faciaların \%51,85'i grizu patlamasından, \%16,40'ı grizu ve kömür tozu patlamasından, \%6,88'i kömür tozu patlamasından kaynaklanmıştır. Çalışmada yeraltı kömür madenlerinde meydana gelen büyük felaketleri kontrol altında tutmak için alınması gerekli önlemlere de değinilmiştir.

Anahtar Kelimeler: Kömür, Maden, Kaza, Türkiye, Çin
\end{abstract}

\section{ABSTRACT}

Underground coal mining is very dangerous in terms of occupational safety and can cause major accidents. In this study, major mining accidents that have occurred in underground coal mines in the world from past to present have been examined together with their causes. A total of 944 miners lost their lives in 19 disasters that occurred in the underground coal mines between 1983 and 2014 in Turkey, and it was recorded that 78.95\% of the disasters were caused by the firedamp explosion. $63 \%$ of the casualties in major occupational accidents that occurred in underground coal mines in Turkey between 1983 and 2014 were caused by gas explosions. It has also been evaluated in major accidents occurring in other countries. America and China are one of the largest coal producing countries in the world. For this reason, major accidents in underground coal mines in America and China are also analyzed. A total of 13883 miners lost their lives in 623 disasters that took place in the USA between 1839 and $2006.81 .1 \%$ of the disasters were caused by firedamp explosions and $0.3 \%$ by coal dust explosions. In 189 disasters that occurred in China between 1942 and 2016, a total of 13075 people lost their lives and $51.85 \%$ of the disasters were caused by firedamp explosions, $16.40 \%$ by firedamp and coal dust explosions, and $6.88 \%$ by coal dust explosions. The necessary precautions to be taken in order to keep the major disasters under control occurring in the underground coal mines are also stated.

Keywords: Coal, Mine, Accident, Turkey, China

\section{ilknur EROL I ierol@cu.edu.tr}

Çukurova Üniversitesi, Mühendislik Fakültesi, Adana, Türkiye

Çukurova University, Faculty of Engineering, Adana, Turkey

Abdulkadir ÜRÜNVEREN I aurunveren@cu.edu.tr Çukurova Üniversitesi, Mühendislik Fakültesi, Adana, Türkiye

Çukurova University, Faculty of Engineering, Adana, Turkey 


\section{GİRİŞ}

Madencilik doğası gereği, sürekli değişken şartlarla karşı karşıya kalınan faaliyet türüdür. Bu şartlar madenciliği çok yüksek riskli sektörler sınıfına sokmaktadır. İş güvenliği kapsamında madencilik sektörü, ölümlü kaza riskinin yüksek olduğu çalışma kollarından birisidir. Dünya genelinde çalışan sayısı bakımından \%1'lik paya sahip olan maden sektöründe kaza oranı \%8'dir [1-3]. Madencilik sektöründe 2013-2018 yılları arasında yaşanan kazaların \%77’si kömür madenciliğinde gerçekleşmiştir [4].

Türkiye ve dünya madenciliğinde ölüm ve kazaların çoğunluğu kömür ocaklarında yaşanmaktadır [5]. Kömür madenciliğinin önde gelen sorunları grizu patlamaları, kömür tozu patlamaları, ani gaz püskürmesi, göçükler, su baskını, yangınlar ve bunların neticesinde ortaya çıkan olumsuz sonuçlardır.

Ülkemizde, 1983-2016 yılları arasında, grizu patlamaları, göçükler, yangınlar, şev kayması ve su baskınları sebebiyle yaşanan 22 büyük kazada 990 madenci hayatını kaybetmiştir. 1839-2016 yılları arasında ABD'de meydana gelen 623 kazada 13883 madenci ölmüştür. Kazaların \% 81,1'i grizu patlamasından dolayı meydana gelmiştir. Çin'de 1942-2016 yılları arasında kömür madenlerinde 13075 kişi hayatını kaybetmiş ve meydana gelen büyük kazaların $\% 51,85^{\prime}$ i grizu patlamasından, $\% 16,40$ ' grizu ve kömür tozu patlamasından, \%6,88’i kömür tozu patlamasından kaynaklanmıştır.

Diğer ülkelerde meydana gelen kazalar incelendiğinde, Rusya'daki büyük kazaların \%91,67'si gaz patlamasından, $\% 8,33$ 'ü gaz ve kömür tozu patlamasından; Hindistan'daki büyük kazaların \%12,50'si gaz patlaması ve kömür tozu patlamasından, \%12,50'si gaz patlaması ve göçükten, \%12,50'si gaz patlaması ve su baskınından; Ukrayna'da ise $\% 75$ 'i gaz patlamasından, \%8,33’ü gaz patlaması ve göçük- ten dolayı meydana gelmiştir.

Ayrıca gaz patlamasından dolayı 2010 yilında Yeni Zelanda'da 29 kişi, 2000-2006 yılları arasında Endonezya’da 32 kişi, 2006 yilında Meksika’da 65 kişi ve 1972 yılında Zimbabve'de 426 kişi; kömür tozu patlamasından dolayı 1913 yılında Galler'de 439 kişi; gaz ve kömür tozu patlamasından dolayı 1906 yılında ise Fransa'da 1099 kişi hayatını kaybetmiştir.

6331 sayılı İş Sağlığı ve Güvenliği Kanunu’nun 2012'de y1lında yürürlüğe girmesiyle, madencilik sektöründe iş sağlığı ve güvenliği kültürü konusundaki gelişmeler hızlanmıştır. Bu kanunla İSG alanında çeşitli düzenlemeler yapılmış ve tüm işyerlerinde iş güvenliği uzmanı ve işyeri hekimi görevlendirilmesi iş kazası ve meslek hastalıklarına tespit bazlı yaklaşımın değil, ön görücü yaklaşımın benimsenmesi gibi hükümler ilave edilmiştir [5]. Ayrıca, bir işyerinin tüm birimlerindeki tehlikeler ile bunlara bağlı risklerin ve alınması gereken önlemlerin ortaya konduğu risk değerlendirme raporları hazırlanması, tüm çalışanlara İSG konularında düzenli eğitim verilmesi, acil durum planları hazırlanması ve acil durum tatbikatları yapılması gibi mecburiyetler getirilmiştir. İşs sağlığı ve güvenliği tedbirlerini önemseyen, kazaları azaltma konusunda başarılı olan işverenlere, vergi teşviklerinden faydalanma imkânı sunulmuştur. Maden kazalarını azaltma konusunda yapılan bu iyileştirmeler olumlu gelişmeler olmuş ve 2016 yilından bu yana ülkemizde büyük maden kazası meydana gelmemiştir.

İşs sağllğı ve güvenliğinde asıl amaç önleme ve korunmadır. Kömür madenlerinde toplu ölümlere sebep olan riskli durumların ortadan kaldırılması, iş sağlığı ve güvenliği açısından çok önemlidir. Bu çalışmanın amacı, yeraltı kömür madenciliği faaliyetleri için belirtilen tehlikelerin ve risklerin iyi belirlenmesi, büyük maden facialarının olmaması için gerekli önlemlerin alınması ve maden ocaklarında 
6331 sayılı İş Sağlığı ve Güvenliği Kanunu'nun hükümlerinin uygulanabilirliğinin denetiminin sıkı bir şekilde yapılmasının sağlanmasıdır. Madencilerin sağlığı, işverenin yükümlülükleri ve ülke ekonomisi için oldukça önemlidir.

\section{YERALTI KÖMÜR MADENLERİNDE GÖRÜLEN BÜYÜK MADEN KAZALARININ NEDENLERİ}

Madencilik doğası gereği riskli iş kollarından biridir. Kömür madenciliği, madencilik sektörü içinde en riskli olanıdır. Özellikle yeraltı kömür madenlerinde meydana gelen kazalar, toplu ölümler ve ciddi yaralanmalarla sonuçlanabilmektedir [6].

Kömür madenlerinde gerçekleşen yangınlar, insan ve ekonomik kayıplara neden olmaktadır. Kömürün kendiliğinden yanması, tahkimatın, bant ve ihraç tesislerinin yanması sonucu ortaya çıkan ocak yangınları hem iş sağlığı ve güvenliğini tehlikeye sokmakta hem de üretimde aksama veya durmalara neden olmaktadır. Kontrol altına alınamayan yangınlar, grizulu ocaklarda patlamaların bir diğer sebebidir. Ocak yangınlarının en büyük zararı, yangınlar sonucu ortamda bulunan zehirli ve boğucu gazların çok sayıda çalışanın ölümüne ve büyük rezervlerin terkedilmesine neden olmasıdır [7]. Şekil 1'de dünyadaki en ölümcül maden kazaları gösterilmektedir. Çin, Fransa ve Japonya vb. dünyanın birçok ülkesinde maden ocaklarında meydana gelen kazalar sonucunda çok sayıda çalışan hayatını kaybetmiştir. En çok ölümlü maden kazası, Çin'de, 1942 yılında, metan gazı ve kömür tozu patlamasından dolayı meydana gelmiş ve 1549 kişi yaşamını yitirmiştir.

Ülkemizde yaşanan en kötü maden facialarından biri 1992 yılında Zonguldak ili Kozlu ilçesinde bulunan Türkiye Taşkömürü Kurumu (TTK) Kozlu Taşkömürü İşletme Müessesesi ocaklarında meydana gelmiş ve grizu patlamasından dolayı 263 madenci hayatını kaybetmiştir. Ayrıca,
2014 yılında 301 madencinin öldüğü Manisa ili Soma ilçesinde yaşanan maden kazası "Cumhuriyet tarihinin en büyük madencilik faciası” olarak kayıtlara geçmiştir.

Madenciliğin kendisine özgü sıkça karşılaşılan felaket türleri bulunmaktadır. Bunlar, kömür madenciliğinde grizu ve kömür tozu patlaması, göçük, ocak yangınları ve su baskınlarıdır.

Şekil 1: Dünya'daki en ölümcül maden kazaları.

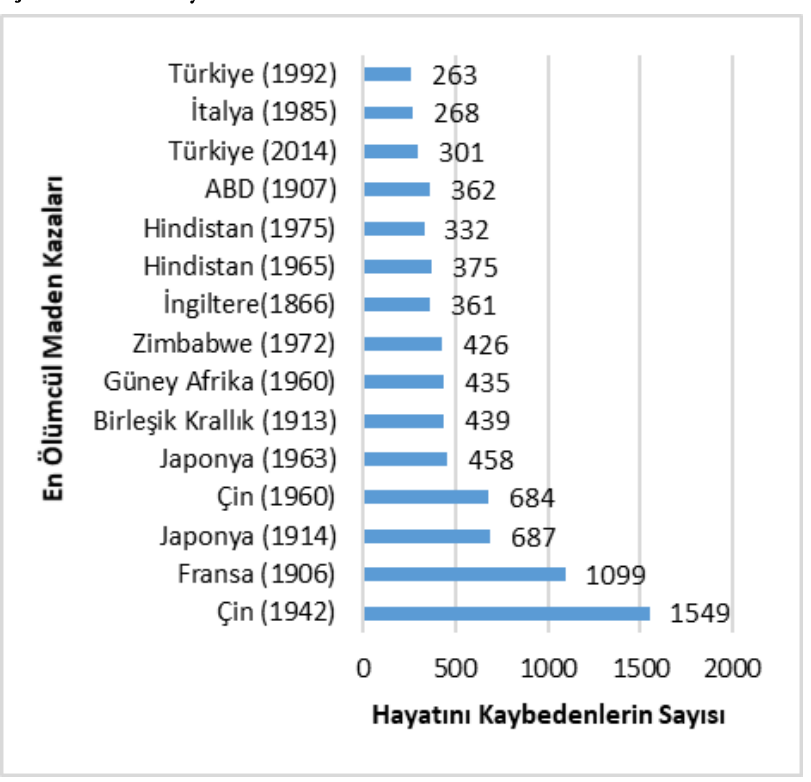

\section{A. Grizu Patlaması}

Maden ocağı ortamında bulunan gazlarının en tehlikelisi metan gazıdır. Metan gazı ocak havasına, normal yayılım ya da ani gaz ve kömür püskürmesi şeklinde karışmaktadır. Metan gazı ile havanın karışımı grizu olarak adlandırılmaktadır. Metan gazı ocak ortamında \%5,4 ile \%14,8 arasında bulunduğunda patlayıcı bir özelliğe sahiptir. Metan gazının hava ile karışımı yanıcı, patlayıcı ve boğucu özellikler taşımaktadır. Metan gazının patlayıcı gaz olması en tehlikeli husustur. En şiddetli patlama \%9,5 metan ile \%90,5 oranında havanın karışması esnasında gerçekleşmektedir [8]. Grizu patlamasının sebepleri:

- Patlayıcı kullanımı ve ateşleme 
- Yangın nedeniyle açık alev oluşumu

- Elektriksel ark oluşumu

- Egzoz gazları

- Metal sürtünmeleriyle kıvılcım oluşumu

- Kayaç sürtünmesiyle kıvılcım oluşumu

- Metal ile kayaç sürtünmesiyle kıvılcım oluşumu şeklinde sıralanabilir [9].

1958-1980 yılları arasında İngiltere’de, hazırlık ve üretim çalışmalarında mekanizasyona ağırlık verilmesi sürecinde metalin kayaca sürtünmesinden dolayı çok sayıda grizu patlaması meydana gelmiştir $[10,11]$.

\section{B. Kömür Tozu Patlaması}

Kömür ocaklarında oluşan patlamaların nedenleri kömür tozunun tek başına patlaması ya da başlamış bir patlamanın toz patlamasını tetiklemesidir. Büyük maden kazalarına yol açan patlamalarda ilk akla gelen neden toz patlamasıdır.

Havada askıda bulunan toz bulutunun bir ateşleyici kaynakla temas etmesiyle toz patlamaları meydana gelmektedir. Patlamada mühim olan tavan, taban ve yan duvarlarda biriken tozun bir darbe etkisiyle girdaplanarak havaya karışmasıdır. Çöken tozu havalandıracak bir etken ile toz bulutunu ateşleyecek bir kaynağın bir araya gelmesi neticesinde toz patlaması oluşmaktadır. $\mathrm{Bu}$ durum, genellikle grizu patlamaları ve patlayıcı maddelerle yapılan ateşlemelerde meydana gelmektedir [12].

\section{Göçük}

Tahkimat, madencilik faaliyeti sonucu açılan boşluğun sürekli emniyetli şekilde tutulması için alınan önlemlerdir. Ayrıca, kazı işleminden sonra uygulanan en önemli faaliyettir. Göçük, yeraltı maden işletmesinde genellikle arındaki, tahkimat yetersiz olduğunda veya tavanın taşıma gücünü kaybederek çökmesi sonucunda meydana gelmektedir [13].

\section{Ocak Yangınları}

Yeraltı kömür madenciliğinde en önemli iş güvenliği problemlerinden biri açık ocak yangınlarıdır. Grizulu ocaklarda, kontrol altına alınamayan yangınlar patlamalara neden olabilir. Ocak yangınlarındaki en kritik durum, metan gibi ocak gazlarını patlatmasının yanı sıra, yangının, zehirleyici ve zararlı gazlar ile ocak içindeki alanlara doğru yayılarak büyümesi ve bunun sonucunda, yangın sebebiyle meydana gelen zehirleyici ve boğucu gazlardan dolayı çok sayıda çalışanın hayatını kaybetmesidir. Ocak yangınlarının başlıca nedenleri aşağıda sıralanmaktadır.

- Mekanik sürtünme nedeniyle meydana gelen yangınlar

- Elektrik kaynaklı yangınlar

- Lağım (dinamit) atma

- Sigara ve benzeri nedenler ve açık alev

- Yanabilen malzemelerin tutuşması

- Kömürün kendiliğinden yanması

- Kaynak işlemleri

- Metan gazı patlamaları [14].

\section{E. Su Baskını}

Yeryüzü ve yerkabuğunun tabakalarındaki suyun varlığı, biriktiği yeraltı boşluklarında ani su baskınlarına sebebiyet vermektedir. Maden ocağına çok fazla miktarda suyun basması çok sayıda çalışanın ölümüne neden olmaktadır. Ayrıca su baskını kazaları çalışanları kurtarma işini zorlaştıran şartların oluşumuna da yol açmaktadır [13]. Bunun yanı sıra maden işletmelerindeki fazla su geliri ocaklarda tavanın ve arının stabilitesini bozarak göçük oluşmasına yol açabilir ve madencilik faaliyetlerini durma noktasına getirebilir. Gerekli önlemler alınmadığı durumlarda büyük facialar kaçınılmaz olacaktır $[15,16]$. 


\section{TÜRKIYE’DE VE ÇEŞITTLİ ÜLKELERDEKI KÖMÜR MADENLERINNDE YAŞANMIŞ BÜYÜK MADEN KAZALARI}

\section{A. Türkiye’de Meydana Gelen Büyük Maden Kazaları}

Büyük maden kazalarının çoğunluğu patlamalar (grizu ve kömür tozu), göçük, su baskını, ocak yangını ve ani gaz püskürmesinden dolayı yeraltı kömür madenlerinde meydana gelmektedir. Tablo 1'de 1983-2016 yılları arasında Türkiye'de meydana gelen büyük maden kazaları nedenleri ile birlikte yer almaktadır. Bu yıllar arasında toplam 22

Tablo 1: Türkiye'deki meydana gelen büyük maden kazaları ve nedenleri

\begin{tabular}{|c|c|c|c|}
\hline Yer & Yıl & Neden & $\begin{array}{l}\text { Ölü } \\
\text { Sayısı }\end{array}$ \\
\hline TTK/Armutçuk/Zonguldak & 7.03 .1983 & $\begin{array}{l}\text { Grizu } \\
\text { Patlaması }\end{array}$ & 103 \\
\hline TTK/Kozlu/Zonguldak & 10.04.1983 & $\begin{array}{l}\text { Grizu } \\
\text { Patlaması }\end{array}$ & 10 \\
\hline Yeni Çeltek/Amasya & 14.07.1983 & $\begin{array}{l}\text { Grizu } \\
\text { Patlaması }\end{array}$ & 5 \\
\hline TTK/Kozlu/Zonguldak & 31.01 .1987 & Göçük & 8 \\
\hline TTK/Amasra/Bartin & 31.01 .1990 & $\begin{array}{l}\text { Grizu } \\
\text { Patlaması }\end{array}$ & 5 \\
\hline Yeni Çeltek/Amasya & 7.02 .1990 & $\begin{array}{l}\text { Grizu } \\
\text { Patlaması }\end{array}$ & 68 \\
\hline TTK/Kozlu/Zonguldak & 3.03 .1992 & $\begin{array}{l}\text { Grizu } \\
\text { Patlaması }\end{array}$ & 263 \\
\hline Sorgun/Yozgat & 26.03.1995 & $\begin{array}{l}\text { Grizu } \\
\text { Patlaması }\end{array}$ & 37 \\
\hline Aşkale/Erzurum & 8.08 .2003 & $\begin{array}{l}\text { Grizu } \\
\text { Patlaması }\end{array}$ & 8 \\
\hline Ermenek/Karaman & 22.11 .2003 & $\begin{array}{l}\text { Grizu } \\
\text { Patlaması }\end{array}$ & 10 \\
\hline Bayat/Çorum & 9.08 .2004 & $\begin{array}{l}\text { Grizu } \\
\text { Patlaması }\end{array}$ & 3 \\
\hline Küre/Kastamonu/Metal & 8.09 .2004 & Ocak Yangını & 19 \\
\hline Gediz/Kütahya & 21.04 .2005 & $\begin{array}{l}\text { Grizu } \\
\text { Patlaması }\end{array}$ & 18 \\
\hline Dursunbey/Balıkesir & 2.06 .2006 & $\begin{array}{l}\text { Grizu } \\
\text { Patlaması }\end{array}$ & 17 \\
\hline Mustafakemalpaşa/Bursa & 10.11.2009 & $\begin{array}{l}\text { Grizu } \\
\text { Patlaması }\end{array}$ & 19 \\
\hline Dursunbey/Balıkesir & 23.02 .2010 & $\begin{array}{l}\text { Grizu } \\
\text { Patlaması }\end{array}$ & 13 \\
\hline TTK/Karadon/Zonguldak & 17.05 .2010 & $\begin{array}{l}\text { Grizu } \\
\text { Patlaması }\end{array}$ & 30 \\
\hline $\begin{array}{l}\text { Elbistan/Kahramanmaraş/ } \\
\text { Linyit }\end{array}$ & 6.02 .2011 & Şev Kayması & 11 \\
\hline TTK/Kozlu/Zonguldak & 8.01 .2013 & $\begin{array}{l}\text { Ani Gaz Püs- } \\
\text { kürmesi }\end{array}$ & 8 \\
\hline Soma/Manisa & 13.5.2014 & Ocak Yangını & 301 \\
\hline Ermenek/Karaman & 28.10 .2014 & Su Baskını & 18 \\
\hline Şirvan/Siirt & 17.11.2016 & Şev Kayması & 16 \\
\hline Toplam & & & 990 \\
\hline
\end{tabular}

adet büyük maden kazası meydana gelmiştir. Bu kazalar sonucu toplam 990 kişi hayatını kaybetmiştir. Yeraltı kömür madenlerinde meydana gelen kazalardan 15 tanesi grizu patlaması, 1 tanesi göçük, 2 tanesi ocak yangını, 1 tanesi su baskını, 2 tanesi şev kayması ve 1 tanesi ani gaz püskürmesi kaynaklıdır.

1983-2014 yılları arasında yeraltı kömür madenlerinde grizu patlaması sonucu meydana gelen kazalarda 609 kişi, göçük nedeniyle 8 kişi, ocak yangını nedeniyle 301 kişi ve su baskını nedeniyle 18 kişi olmak üzere toplam 944 kişi hayatını kaybetmiştir [17]. Ülkemizde, 1983-2014 yılları arası, kömür madenciliği için en ölümlü dönem olarak anılmaktadır (Şekil 2). Bu yıllar arasında, yeraltı kömür madenlerinde toplam 19 maden felaketi yaşanmış ve 944 madenci yaşamını yitirmiştir.

2014 yilında Soma-Eynez kömür madeninde meydana gelen ocak yangınında 301 madenci hayatını kaybetmiş ve 122 madenci ise yaralanmıştır. Soma kazası, Türkiye Cumhuriyeti madencilik tarihinde can kaybının en çok olduğu maden kazasıdır.

İSG alanında yapılan düzenlemeler sayesinde iş güvenliği kültürü madencilik sektöründe iyice benimsenmeye başlamıştır. Bu durumun bir sonucu olarak, yeraltı kömür madenlerinde 2014 yılından bu tarihe kadar büyük bir maden kazası meydana gelmemiştir.

Şekil 2: Yeraltı kömür madenlerinde meydana gelen büyük kazalarda hayatını kaybedenlerin sayısı

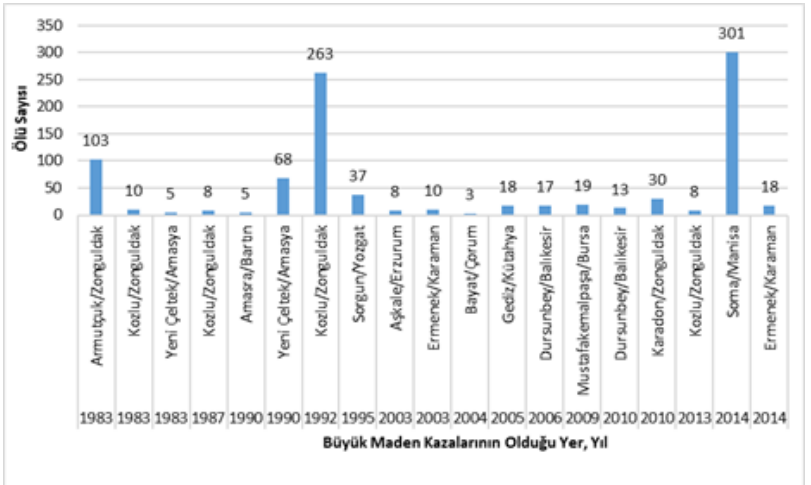


Şekil 3: ABD’de kömür madenlerinde yaşanan maden faciaların nedenleri (\%)

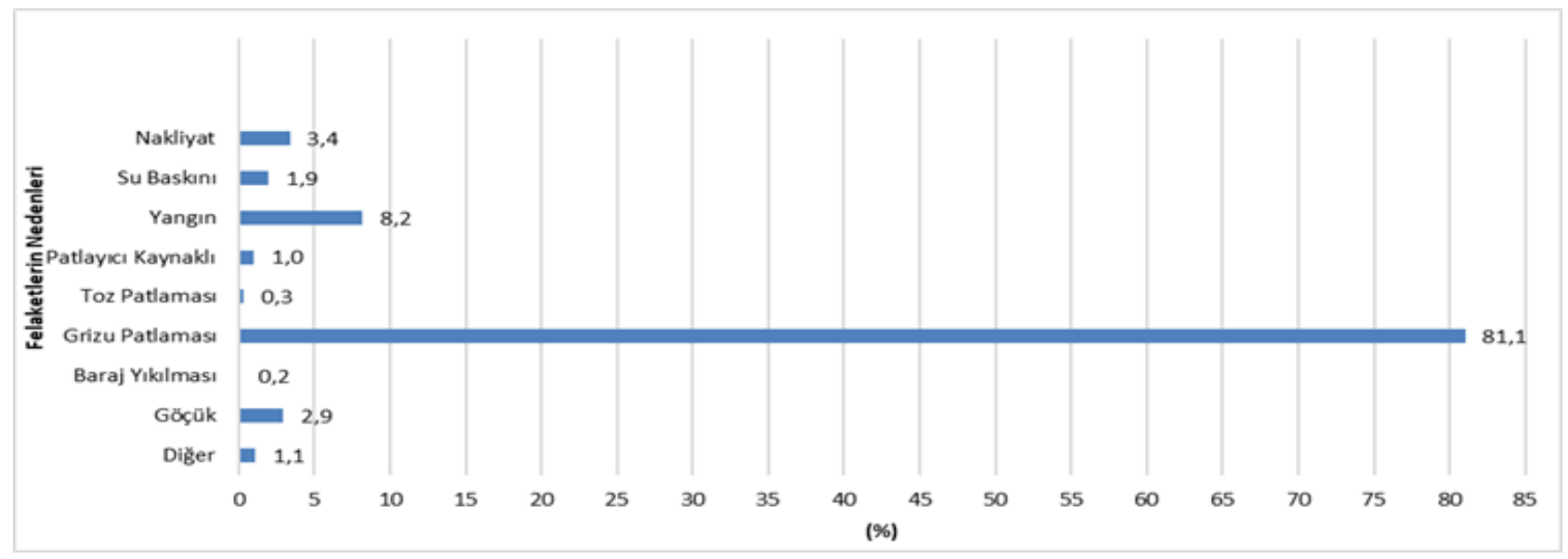

\section{B. Dünyada Meydana Gelen Büyük Maden Kazaları}

\section{Amerika}

1839 yılından bu yana Amerika'da yeraltı kömür madenlerinde binlerce maden işçisinin ölümüyle sonuçlanan yüzlerce büyük facia meydana gelmiştir (Tablo 2.). Amerika'daki maden faciaları grizu patlaması, göçük, su baskını, yangın, nakliyat kazaları, gazdan boğulma, toz patlaması, baraj yıkılması, patlayıcı kaynaklı ve diğer nedenler dolayı gerçekleşmiştir [18]. ABD’de yeraltı kömür madenlerinde meydana gelen felaketlerinin \%81,1'i grizu patlamasından kaynaklanmaktadır. Felaketlerin \%8,2'lik kısmı da ocak yangınlarından dolayı meydana gelmiştir (Şekil 3).

ABD'de birçok bölgede kömür madeni işletilmektedir. Pennsylvania, Kentucky, Alabama ve Illinois bölgelerinde

Tablo 2: 1839-2010 yılları arası ABD'de felaket türüne göre ölenlerin sayısı [19]

\begin{tabular}{lcc}
\hline Felaketlerin Nedenleri & Felaket Sayısı & Ölü Sayısı \\
\hline Nakliyat & 21 & 145 \\
Su Baskını & 12 & 187 \\
Yangın & 51 & 999 \\
Patlayıcı Kaynaklı & 6 & 126 \\
Toz Patlaması & 2 & 34 \\
Grizu Patlaması & 493 & 12038 \\
Baraj Yıkılması & 1 & 114 \\
Göçük & 18 & 184 \\
Diğer & 7 & 56 \\
\hline Toplam & $\mathbf{6 1 1}$ & $\mathbf{1 3 8 8 3}$ \\
\hline
\end{tabular}

meydana gelen kaza sayıları oldukça fazladır (Tablo 3). Bu felaketlerin \%29,9'u Pennsylvania bölgesindeki maden işletmelerinde meydana gelmiştir. Batı Virginia bölgesinde bulunan maden işletmelerinde meydana gelen felaketlerin oranı ise \%16,2'dir.

Tablo 3: ABD'de büyük maden kazalarının yaşandığı bölgeler ve maden işletmeleri [19]

\begin{tabular}{|c|c|c|}
\hline \multicolumn{2}{|c|}{ Felaketin Olduğu Bölgeler } & \multirow{2}{*}{$\frac{\text { Felaket Sayısı }}{2}$} \\
\hline AK & Alaska & \\
\hline$A L$ & Alabama & 39 \\
\hline AR & Arizona & 8 \\
\hline CA & Kalifornia & 2 \\
\hline $\mathrm{CO}$ & Colorado & 32 \\
\hline IA & lowa & 3 \\
\hline IL & Illinois & 39 \\
\hline IN & Indiana & 15 \\
\hline KS & Kansas & 4 \\
\hline KY & Kentucky & 40 \\
\hline MD & Maryland & 3 \\
\hline $\mathrm{MN}$ & Minnesota & 1 \\
\hline MO & Missouri & 2 \\
\hline MT & Montana & 3 \\
\hline NC & Kuzey Carolina & 4 \\
\hline NM & New Mexico & 12 \\
\hline $\mathrm{OH}$ & Ohio & 14 \\
\hline OK & Oklahoma & 26 \\
\hline PA & Pennsylvania & 186 \\
\hline $\mathrm{TN}$ & Tennessee & 12 \\
\hline UT & Utah & 10 \\
\hline VA & Virginia & 28 \\
\hline WA & Washington & 20 \\
\hline WV & Bat Virginia & 2 \\
\hline WY & Wyoming & 14 \\
\hline Toplam & & 520 \\
\hline
\end{tabular}


1839-2010 yılları arasında ABD’de yeraltı kömür madenlerinde meydana gelen facialarda hayatını kaybedenler Şekil 4'te gösterilmiştir.

Şekil 4: 1839-2010 yılları arasında ABD’de meydana gelen facialarda hayatını kaybedenlerin sayısı

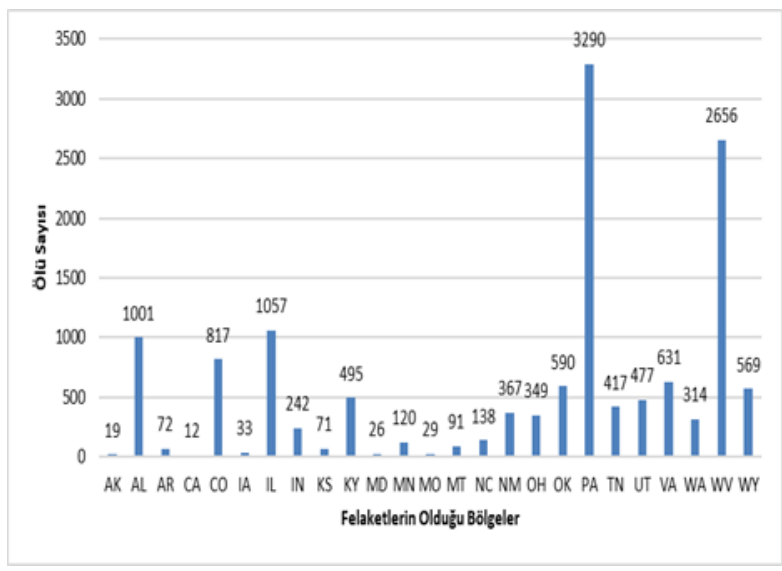

"Kanlı Aralık" olarak bilinen Aralık 1907, ABD yeraltı kömür madenciliği kayıtlarına geçen en ölümlü dönem olmuştur. O ay 703 madenci, 5 maden patlamasında ölmüştür.

Monongah No. 6 ve 8 felaketi, Darr felaketi ve Cherry felaketi ABD kömür madenlerindeki en ölümcül olaylardan 3'ü olmuştur. 1839-2010 yılları arasında ABD'de 623 yeraltı kömür madenciliği felaketinde, 13883 madenci hayatını kaybetmiş ve felaketlerin çoğunluğu grizu patlamalarından kaynaklanmıştır [19, 20].

Maden Bürosunun (Bureau of Mines) kurulmasıly birlikte $\mathrm{ABD}$ madenciliğinin iş sağlı̆̆ı ve güvenliği alanında önemli düzenlemeler olmuş ve 1910-1969 yıları arasında afetler önemli ölçüde azalmıştır. 1992'deki South Mountain'de gerçekleşen patlamadan sonra, 2001 yılına kadar büyük bir kömür madeni felaketi yaşanmamıştır.

\section{2. Çin}

Çin'de 1942-2016 yılları arası meydana gelen 189 yeraltı kömür madenciliği felaketinde, 13075 madenci hayatını kaybetmiş ve felaketlerin çoğunluğu grizu patlamala- rından kaynaklanmıştır (Tablo 4.) 1949-2009 yılları arasındaki büyük maden kazalarına bakıldığında, ölüm oranlarının giderek azaldığı görülmektedir. Çin’de 1960 yılında kömür tozu patlamasından dolayı 684 kişinin ölmüş ve can kaybının çok olduğu kaza olarak kayıtlara geçmiştir [21].

Çin'de meydana gelen felaketlerin büyük çoğunluğunu grizu patlaması ve kömür tozu patlaması oluşturmaktadır

Tablo 4: 1942-2016 yılları arasında Çin'de yaşanan maden felaketleri [22-24]

\begin{tabular}{lcc}
\hline Felaketlerin Nedenleri & Felaket Sayısı & Ölü Sayısı \\
\hline Grizu Patlaması & 98 & 5373 \\
Grizu ve Kömür Tozu Patla- & 31 & 3743 \\
ması & 10 & 509 \\
Ani Gaz Püskürmesi & 13 & 1525 \\
Kömür Tozu Patlaması & 13 & 671 \\
Ocak Yangını & 21 & 1137 \\
Su Baskını & 3 & 117 \\
Patlayııı Kaynaklı & $\mathbf{1 8 9}$ & $\mathbf{1 3 0 7 5}$ \\
\hline Toplam &
\end{tabular}

1942 yılı Çin için en ölümlü yıl olmuştur. Liaoning bölgesinde meydana gelen faciada, grizu ve kömür tozu patlamasından dolayı 1549 kişi hayatını kaybetmiştir. 1960 yılında Shanxi bölgesinde kömür tozu patlamasından dolayı 684 kişi hayatını kaybetmiştir. Aynı yıl Shanxi bölgesinde bir başka grizu patlamasından dolayı 38 kişi ölmüştür. Chongquing bölgesinde, ani gaz püskürmesi ve kömür tozu patlamasından kaynaklanan 2 büyük kazada toplam 249 kişi hayatını kaybetmiştir. Ayrıca aynı yıl Henan bölgesinde grizu ve kömür tozu patlamasından dolayı 187 kişi ölmüştür. Özetle 1960 yılında Çin'de büyük kazalardan dolayı toplam 1158 kişi hayatını kaybetmiştir. 2005 yılında, grizu patlaması, kömür tozu patlaması ve su baskınından dolayı, Liaoning, Shanxi, Jilin, Hebei, Xinjiang, Guangdong, Henan, Heilongjiang bölgelerinde toplam 11 büyük kaza meydana gelmiş, toplam 853 kişi hayatını kaybetmiştir (Şekil 5). 
Şekil 5: 1942-2016 yılları arasında Çin'de yeraltı kömür madenlerinde meydana gelen büyük kazalar [19]

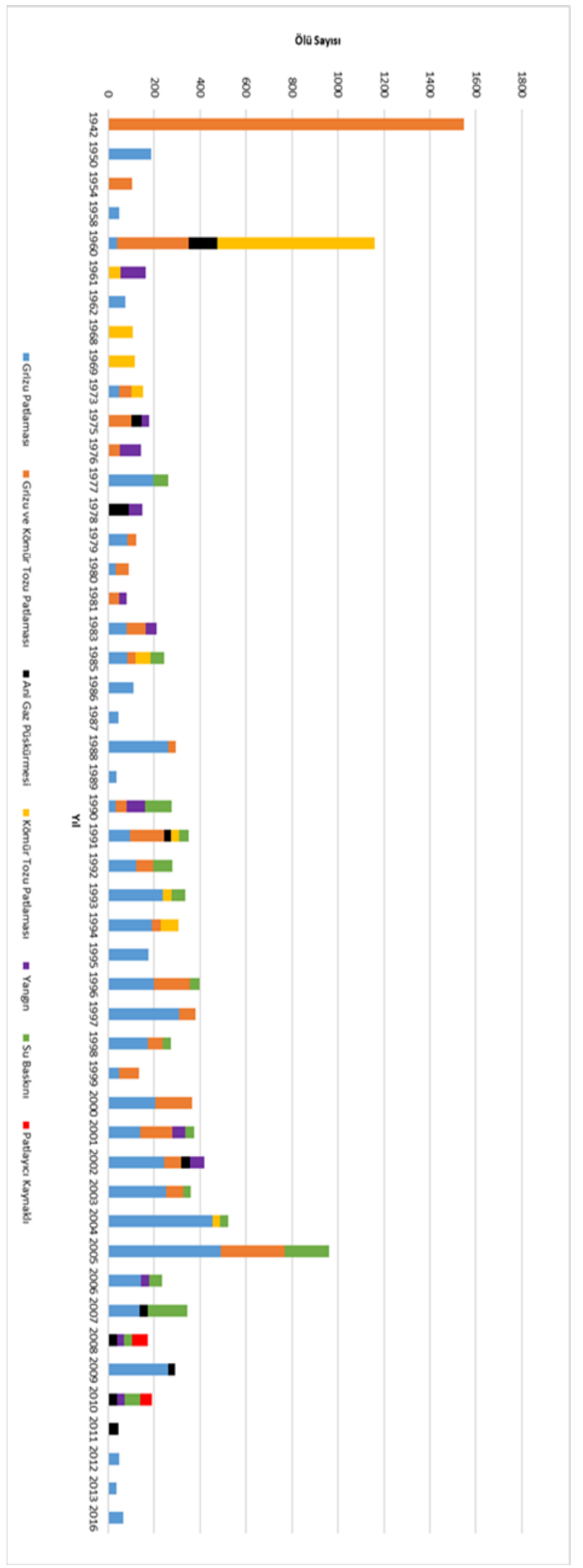

Şekil 6'da görüldügü üzere Çin'de yeraltı kömür madenlerinde meydana gelen felaketlerinin $\% 51,85$ ’ $\mathrm{i}$ grizu patlamasından kaynaklanmaktadır. Felaketlerin \%16,40’lık kısmı grizu ve kömür tozu patlamasından; \%11,11'lik kıs$\mathrm{m} ı$ ise su baskınından dolayı meydana gelmiştir.

Şekil 6: Çin'de kömür madenlerinde yaşanan maden faciaların nedenleri (\%)

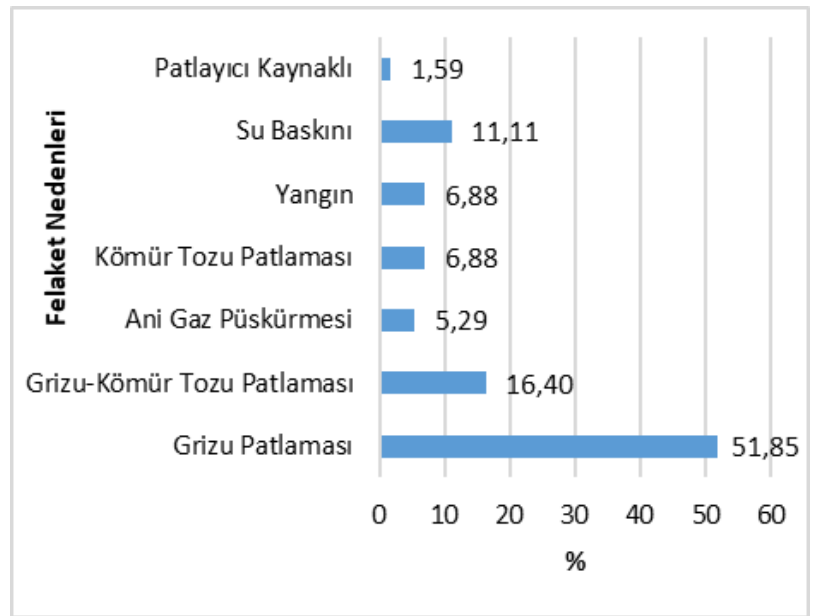

Çin'de yaşanan felaketlerin \%22,75'i Shanxi bölgesinde bulunan maden işletmelerinde meydana gelmiştir. Henan $(\% 13,76)$ ve Hebei $(\% 12,70)$ bölgesinde bulunan maden işletmelerinde meydana gelen felaketlerin oranı ise birbirine oldukça yakındır. 1942-2016 yılları arasında Çin'de yeraltı kömür madenlerinde meydana gelen facialarda hayatını kaybedenler Şekil 7’de gösterilmiştir. En fazla ölü sayısı Shanxi bölgesinde meydana gelen kazada olmuştur.

Şekil 7: Çin'de meydana gelen facialarda hayatını kaybedenlerin sayısı

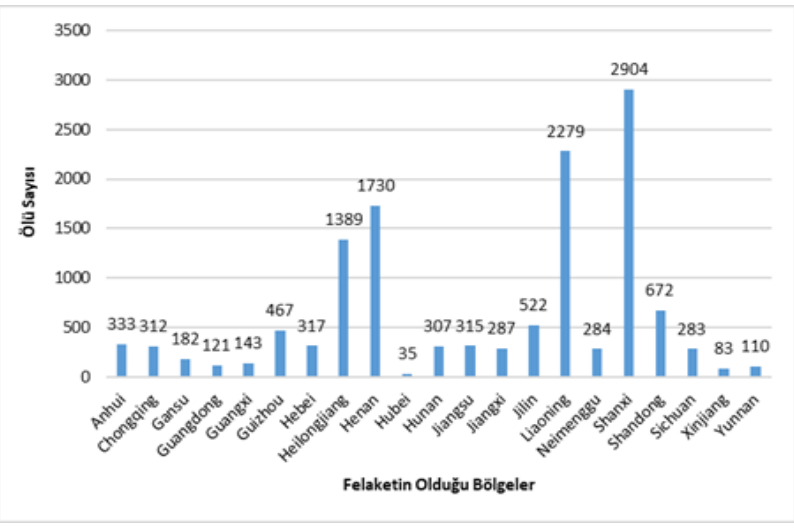




\section{Diğer Ülkeler}

Rusya'da 2000-2016 yılları arasında gaz ve kömür tozu patlamasından dolayı toplam 12 büyük kaza meydana gelmiştir. Kazaların çoğunluğu grizu patlamasından kaynaklanmıştır. En büyük felaket ise 2010 yllında Raspadskaya bölgesinde grizu patlamasından dolayı meydana gelmiş ve 90 kişi hayatını kaybetmiştir. İkinci büyük felaket ise Tayzhina bölgesinde yine grizu patlamasından dolayı olmuştur 47 kişi yaşamını yitirmiştir. 2002 ve 2013 yıllarında Vorkuntinskaya bölgesinde grizu patlamasından dolayı 2 ayrı felaket meydana gelmiş ve toplam 30 kişi hayatını kaybetmiştir (Şekil 8) Rusya’da 2007 yılında Ulyanovskaya bölgesinde grizu ve kömür tozu patlamasından dolayı 1 tane büyük kaza meydana gelmiş ve 10 kişi hayatını kaybetmiştir. Sadece grizu patlamasından dolayı meydana gelen kazaların oranı \%91,67'dir.

Şekil 8: Rusya'da meydana gelen facialarda hayatını kaybedenlerin sayıs

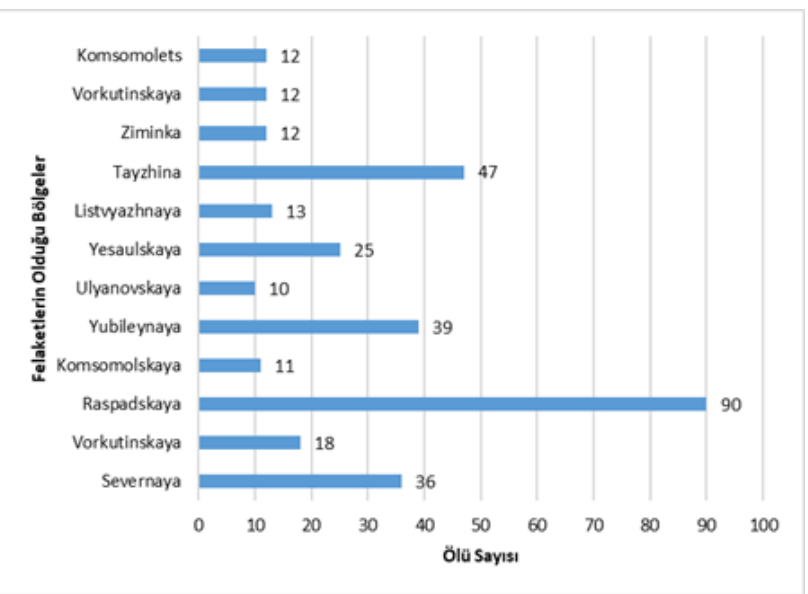

Ukrayna'da 2000-2015 yılları arasında toplam 11 büyük kaza meydana gelmiş ve toplam 427 kişi hayatını kaybetmiştir. Felaketler Zasyadko, Barakova, Ukrania, Donbass, Karl Marx, Skochinsky, Bazhanov, SukhodislskaSkhidna bölgelerinde olmuştur (Şekil 9). Zasyadko bölgesinde 2001, 2002, 2006, 2007 ve 2015 yilinda 5 ayrı felaket olmuştur. Ukrayna’nın en büyük felaketi bu bölgede
2007 yılında gaz patlamasından dolayı meydana gelmiş ve 101 kişi hayatını kaybetmiştir. Ukrayna’da meydana gelen kazalar gaz patlaması (\%75), gaz patlaması ve göçük (\% $8,33)$, yangın $(\% 8,33)$ ve diğer nedenlerden $(\% 8,33)$ dolayı meydana gelmiştir.

Şekil 9: Ukrayna’da meydana gelen facialarda hayatını kaybedenlerin sayısı

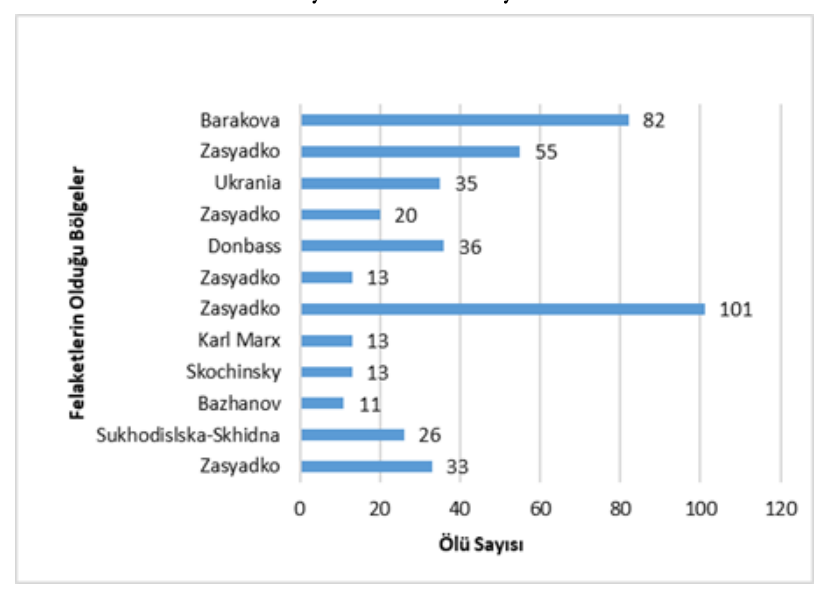

Pakistan'da ard arda iki yll (2010 ve 2011 yılında) grizu patlamasından dolayı maden kazası meydana gelmiş ve Dukki bölgesinde bu nedenle 52 kişi, Al-Rahman bölgesinde 10 kişi hayatını kaybetmiştir.

Kolombiya'da 2007 ve 2010 yilında grizu patlamasından dolayı büyük maden kazası meydana gelmiştir. 2007 yilında Norte de Santander bölgesinde 32 kişi, 2010 yılında San Femando bölgesinde ise 73 kişi hayatını kaybetmiştir.

Polonya'da 2002, 2006 ve 2009 yıllarında büyük maden kazası meydana gelmiştir. Jas-Mos Bölgesinde 10 kişi, Halemba bölgesinde 23 kişi, Wujek-Slask bölgesinde 20 kişi grizu patlamasından dolayı yaşamını yitirmişsir.

Kazakistan'da 2006 ve 2008 yıllarında meydana gelen kazada Mittal's Lenin bölgesinde 41 kişi, Abaiskaya bölgesinde ise 30 kişi grizu patlamasından dolayı hayatını kaybetmiş̧tir. 
Hindistan'ın Dhori bölgesinde 1965 yilında ve Chasnala bölgesinde 1975 yılında iki büyük felaket meydana gelmiştir. Dhori bölgesinde grizu ve kömür tozu patlamasından dolayı 375 kişi; Chasnala bölgesinde ise gaz patlaması ve su baskını nedeniyle 372 kişi hayatını kaybetmiştir (Şekil 10). Hindistan'da meydana gelen felaketlerin \% 37,50'si su baskınından, \%25'i göçükten, \%12,50'si grizu patlaması ve su baskınından, \%12,50'si gaz patlaması ve göçükten, \%12,50’si grizu ve kömür tozu patlamasından kaynaklanmıştır.

Şekil 10: Hindistan'da meydana gelen facialarda hayatını kaybedenlerin sayısı

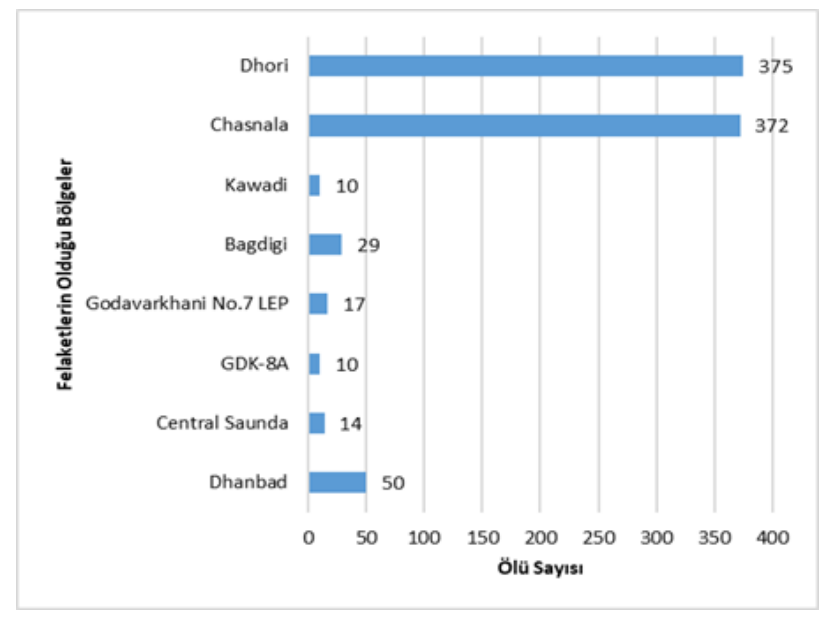

1866 y1lında İngiltere'de, Güney Yorkshire’daki Oaks kömür ocağında grizu ve kömür tozu patlamasından dolayı 361 kişi hayatını kaybetmiştir.

1914 yılında Japonya’nın Mitsubisi Hojyo bölgesinde grizu ve kömür tozu patlamasından dolayı 687 kişi;.1963 yılında Mitsu Miike bölgesinde kömür tozu patlamasından dolayı 458 kişi hayatını kaybetmiştir.

1972 yllında Zimbabve'nin Wankie bölgesinde patlama gerçekleşmiş 426 kişi hayatını kaybetmiştir.

1906 yılında Fransa'nın Courrieres bölgesinde grizu ve kömür tozu patlamasından dolayı 1099 kişi; 1913 yılında Galler'in Senghenydd bölgesinde kömür tozu patlamasın- dan dolayı 439 kişi yaşamını yitirmiştir.

1960 yılında Güney Afrika’da Coalbrook’da göçük olmuş ve 435 kişi ölmüştür. Gaz patlamasından dolayı 2006 yılında Meksika’nın Pasta de Conchos bölgesinde 65 kişi; 2009 yılında Endonezya'nın Sarana Arang Sejati bölgesinde 32 kişi; 2010 yılında Yeni Zelanda'nın Pike River bölgesinde 29 kişi hayatını kaybetmiştir.

Geçmişten günümüze dünyada meydana gelmiş büyük maden kazaları sınıflandırıldığında, patlamalar (gaz ve toz) nedeniyle olan kazaların, yeraltı kömür madenciliğinin birincil sorunları olduğuna işaret etmektedir.

\section{YERALTI KÖMÜR MADENLERİNDE ALIN- MASI GEREKEN TEDBİRLER}

\section{A. Grizu Patlamaları ile Mücadelede}

Grizu patlamaları, kömür madenlerinde en ölümcül kazalar olarak karşımıza çıkmaktadır. Ocak ortamında yapılan ölçümlerde metan gazı eser miktarda olsa dahi grizulu ocak olarak kabul edilir. Grizulu ocaklarda metan konsantrasyonlarının ölçümleri, vardiyalarda daimi nezaretçi veya yetkili personel tarafindan yapılmakta ve sonuçlar emniyet defterine yazılmaktadır.

Grizu patlamalarının önlemesi amacıyla ocak ortamında alınması gereken önlemler ve uyulması gerekli kurallar vardır. Maden ocaklarında metan konsantrasyonunun \%1 olduğunda, patlatma yapılmamakta ve çalışmalar durdurulmaktadır. \%1,5 metan konsantrasyonunda elektrik enerjisi kesilmekte ve \%2'lik metan konsantrasyonunda ise ocak boşaltılmaktadır. Metan konsantrasyonu \%1,5’u aşan yerlerde iletkenlerin ve elektrikli cihazların gerilimi devre dışı bırakılmaktadır.

Grizu ile mücadelede en etkin önlem metan gazı drenajıdır. Havalandırma işlemleri ve drenaj sistemleri, madenlerde metan konsantrasyonunu düşük tutmanın en ekono- 
mik yoludur. Drenaj yapılamadığı zaman havalandırma ile metan konsantrasyonunun, patlama konsantrasyonunun altına düşürülmesi gerekmektedir. Metan gazı riski olan ocaklar için en etkin çözüm gaz izleme ve erken uyarı sisteminin kurulması ve verimli bir şekilde kullanılmasıdır. Liu vd., 2013 yılındaki çalışmalarında kömür madenlerindeki erken uyarı sistemlerinin, grizu patlama riskinin belirlenmesinde ve iş kazalarının azaltılmasında çok fayda sağladığını vurgulamıştır [25].

Ülkemizde metan gazı ile mücadele konusunda "Maden İşyerlerinde İş Sağllğı ve Güvenliği Yönetmeliği’nde, üretim ünitelerinden dönüş havası içinde ve üretim yerlerindeki gazların birikebileceği yerlerde, metan gazı seviyesi sürekli olarak izlenecektir" ibaresi bulunmaktadır. Ayrıca 30 Haziran 2012 tarihinde çıkarılmış olan 6331 sayılı İş Sağlığı ve Güvenliği Kanunu'nda da çalışma şartları ve önlemler konusu detaylı bilgilendirmeler bulunmaktadır. Yönetmelikte "Tehlikeli gaz oranının çalışma ortamında sık sık değiştiği hallerde, metan oranına göre ayarlı ses ve ışık uyarısı yapan gaz dedektörünün bulundurulması veya bir merkezden sürekli olarak izlenebilecek otomatik kontrol sistemi kurulacaktır" ibaresi de mevcuttur [26].

Ocak içerisindeki gazın kontrolü gaz sensörleri ile sağlanmaktadır. Sabit ve el sensörleri olmak üzere iki çeşit sensör vardır. El sensörleri gazlar $\left(\mathrm{CH}_{4}, \mathrm{CO}, \mathrm{O} 2, \mathrm{H}_{2} \mathrm{~S}\right)$ sınır değerleri aştı̆̆ında kişiyi sesli ve ışıklı olarak uyarmaktadır. Sabit sensörler ise gaz geliri riski olan kritik noktalara yerleştirilerek yerüstünde bulunan gaz izleme merkezinde, bilgisayarlar vasıtasıyla izlenebilmektedir.

Merkezi gaz izleme sistemi ile anlık veriler elde edilmektedir. Ayrıca bu sistem tehlikenin arttığı bölgedeki elektrikli makineleri durdurabilme ve elektriğini kesebilme imkânına da sahiptir. Bunun yanısıra merkezi gaz izleme sistemi, otomatik olarak havalandırma amaçlı fanı devreye alabilme, devrini arttırıp azaltabilme ya da durdurabilme özelliğine sahiptir. Gaz değerleri, tehlikeli sınır değerlerin altına indiğinde sistem tekrar makinelerin çalışmasına izin vermektedir. $\mathrm{Bu}$ sisteme insan faktörü uzak tutularak da müdahale etmek mümkündür.

Metan gazı bulunan ocaklarda sadece alev sızdırmaz (exproof veya ATEX sertifikalı) özellikteki cihazlar kullanılmalıdır. Gaz izleme ürünlerinin EXI M1 veya EX I M2 tip sertifikalara sahip olması gerekmektedir. Ocakta ani gaz artışı olduğunda M1 tip ekipman kendisini kapatamamakta ve kritik gaz değerlerini okumaya devam etmektedir. M2 tip ekipman ise ocakta ani gaz artışı olduğunda kendisini kapatmaktadır. Bu nedenle acil durumda kritik olan gaz konsantrasyon değerleri okunamamaktadır. Gaz riski yüksek ocaklarda kesinlikle EXI M1 kendinden emniyetli sistem kullanılmalıdır.

\section{B. Kömür Tozu Patlamaları ile Mücadelede}

Kömür tozu olan özellikle grizulu ocaklarda, şartlar iyi olsa dahi, tozun patlama olasıllğı söz konusudur. Bu nedenle, toz patlamalarının gelişmesini önlemek ve patlamaları durdurmak için tedbirlerin alınması oldukça mühimdir.

Grizu patlamasına ve solunabilir toza karşı alınan önlemler, toz patlamaları ile mücadelede yeterli olmaktadır. Toz patlamalarına karşı alınabilecek önlemler şunlardır:

- Tozun oluşmasını, birikmesini ve havaya karışmasını önlemek

- Tozu ateşleyen kaynağın yok edilmesi

- Toz patlamasının geniş alana yayılımının engellenmesi

Fisketelerle ıslatma, arına su emprenyesi gibi yöntemler bağlanmış olan tozun havalanarak toz bulutu oluşturmasına engellenmektedir. Tozun alevlenebilme özelliğini azaltmak için ıslatmanın yanısıra koruyucu taş tozu ilave edil- 
mektedir. Bu uygulamanın amacı tozun yanmaz malzeme içeriğini arttırmak ve tozun patlamaz duruma gelmesini sağlamaktır.

En çok uygulanan teknik, koruyucu taş tozu serpilmesi denilen şistleme işlemidir. Şistlemede kullanılan taş tozunda silis olmaması istenmektedir. Bu sayede silis kaynaklı risklerin önüne geçilmiş olacaktır. Şistleme yapılan ocaklarda toz defteri tutulmaktadır. Bu defterde, toz numunesinin alındığı yer, tozun alınma tarihi, tozun yanmaz madde içeriği analiz sonucu, ocak içinde taş tozu serpilen bölümler ve tarihleri yazılmaktadır. Şistlemenin etkinliği, düzenli ve sürekli örnek alımı ve alınan numunenin yanmaz madde içeriği analiz sonuçları ile takip edilmektedir. Toz içeren ocaklarda tavan, taban ve tahkimat üzerindeki tozun, ayda en az bir kez denetlenmesi zorunludur. Alınan tedbirlere rağmen oluşan toz patlamasının ocağın diğer kesimlerine yayılımını önlemek için taş tozu ve su barajları yapılmaktadir.

\section{Su Baskını ile Mücadelede}

Yeraltı maden işletmelerinde suyun işyerlerine gelmesini engellenmek ve ortamda bulunan suyun uzaklaştırılmasını sağlamak için çeşitli yöntemler bulunmaktadır. Su baskınları ile mücadelede aşağıda sıralanan yöntemler uygulanabilmektedir.

a) Topuk bırakma: Yeralında su içeren tabaka ile çalışma sahası arasında topuk bırakılarak su baskını sorunu önlenebilmektedir.

b) Dolgulu üretim uygulama: Üretim yapılan bölgede su içeriği yüksek tavan taşı bulunması durumunda dolgulu yöntemle üretim yapılmaktadır.

c) Yeraltı sondajları: Suyun bulunma ihtimalinin yüksek olduğu çalışma bölgelerinde sondajlar ile suyun drenajı mümkündür. d) Sementasyon: Yeraltında fay hatları boyunca gelen su betonlama işlemi ile engellenebilmektedir. Bu işleme semantasyon adı verilmektedir. Çimento şerbeti pompalar yardımıyla fay hatları boyunca enjekte edilerek gelen su kesilebilmektedir.

e) Set yapmak: Yeraltında çevre işyerlerinden gelebilecek sulara engel olmak için setler yapılmaktadır.

f) Baraj yapmak: Maden ocaklarında çok su geliri olan eski çalışma yerleri ile yeni çalışma yerleri kil, ahşap veya beton barajlar ile ayrılmaktadır.

g) Su kapıları: Fazla su geliri olan veya gelen suyun dişarı atılamadığı durumlarda su kapıları kullanılmaktadır. Su kapıları tehlikeli durumlar söz konusu olduğunda kapatılır. Amaç suyun arka tarafta birikmesi sağlamaktır.

h) Pompa ile suyun atımı: İşyeri ortamındaki suyun uzaklaştırılmasında su toplama havuzları ve pompalardan faydalanılmaktadır. Su toplama havuzları suyun toplanması ve süzülmesini sağlamaktadır. Gelen su az ve düzgün ise, kuyu 15-20 m daha derinleştirilmekte ve bu kısım toplama havuzu olarak kullanılmaktadır. Şayet su düzensiz ve fazla ise kuyuya yakın bölgede havuzlar yapmak gerekmektedir. Havuzların büyüklükleri ve sayıları gelen su gelirine bağlıdır. Havuzlarda biriken su, pompalar yardımıyla ocak dışına sevk edilmektedir. Drenaj galerileri ile de birkaç ocağın suyu toplanabilmektedir. Pompanın bozulduğu durumlarda, drenaj galerileri sayesinde madene su basma tehlikesi engellenmektedir [27].

\section{Ocak Yangınları ile Mücadelede}

Kömürün havayla teması sonucu oksidasyon olayı kaçınılmazdır. Üretime başlamadan, kömürün yanmaya karşı duyarlılığı belirlenerek uygun üretim yöntemi seçilmelidir. Ocak yangınlarında en önemli belirteç CO gazıdır. Patlat- 
ma sonrası ortama CO gazı yayılmaktadır. Ayrıca içten yanmalı motorların egzozundan çıkan gazların içinde de $\mathrm{CO}$ gazı bulunmaktadır. Bu nedenlerden dolayı $\mathrm{CO}$ gazının ölçüm değerlerinde ani yükselmeler olabilmektedir. $\mathrm{Bu}$ sebeple patlatmaların yapildığı ve makinelerin çalışı̆ğı zamanlarda bu durum dikkate alınarak CO takibi yapılmalıdır. CO gaz değerlerinin kararlı bir artış göstermesi oksidasyonun şiddetinin bir göstergedir. Artı̧ hangi sensörün alanında okunmuş ise o bölgede manuel gaz ölçüm cihazlarıyla ölçüm yapılarak, CO miktarındaki artışın nereden kaynaklandığı belirlenmelidir [28].

\section{SONUÇ VE ÖNERILER}

Madencilik bilgi, deneyim, uzmanlık ve sürekli denetim gerektiren, değişik çalışma koşulları karşısında sürdürülen bir faaliyettir. Yeraltı kömür madenciliği de, işs sağlığı ve güvenliği açısından özel önlem alınması gereken riskleri bünyesinde barındırmaktadır. Bu sebeple olası risklere karşı hazırlıklı olunmalı ve her an yeni bir tehlike ortaya çıkacakmış gibi önlem alınmalıdır.

Geçmişten günümüze yaşanan büyük maden kazaları, kömür madenlerindeki birincil risklerin gaz ve toz patlamalarının olduğunu ortaya koymaktadır. Ülkemizde yeraltı kömür ocaklarında meydana gelen büyük kazaların nedenlerine bakıldığında daha çok grizu ve kömür tozu patlaması göze çarpmaktadır. Bu kazaların \%78,95’i grizu patlaması olarak kayıtlara geçmiştir. 2014 yılından sonra büyük çaplı kazaların olmamasının bir nedeni olarak iş güvenliği tedbirlerinin daha sıkı uygulanmasıdır.

Grizu patlamalarının, ortamdaki metan gazı konsantrasyonlarının sınır değerleri aştığı zamanın tespit edilmemesinden kaynaklandığı düşünülmektedir. Bu sebeple, gaz izleme ve erken uyarı sistemlerinin kurulması, sürekli ocak havasının izlenmesi ve kayıt altına alınması, kaza sayılarının azalmasındaki bir diğer etken olarak karşımıza çımaktadır.
İnsan faktörü olabildiğince devre dışı bırakılması ve merkezi gaz izleme sistemlerinin kullanımı sayesinde ocak ortamı sürekli kontrol altında tutularak daha sağlıklı çalışma koşulları oluşturulmuştur.

Gaz patlamalarının önlemek, kömür tozu patlamalarına metanın etkisini ortadan kaldırmak için yüzeyden damara delinen düşey kuyularla, yüzeyden göçük bölgesine delinen düşey kuyularla, hazırlık galerilerinden arın önüne delinen yatay delikler ve çevre tabakaya doğru delinen çapraz delikler yöntemleri ile metan drenajı yapılmaktadır. Bu sayede hem patlamaların önüne geçilebilmekte hem de drene edilen gaz birçok alanda ekonomik olarak değerlendirilmektedir. Yeraltı maden ocaklarında exproof cihazların kullanılması da patlamaların önlenmesinde oldukça etkilidir.

Toz içindeki yanmayan madde miktarının en az \%65 olmasının sağlanması, iş sağlığı ve güvenliği açısından oldukça önemlidir. Şistleme işleminin düzenli ve sistematik bir şekilde uygulanması sayesinde son yıllarda yeraltı kömür madenlerinde toz kaynaklı patlamalarının önüne geçilmiştir.

2014 yılından günümüze kadar ülkemizde yeraltı kömür madenlerinde büyük maden kazalarının meydana gelmemesindeki en büyük etkenlerin; mevzuatta yapılan değişiklikler, işs sağlığı ve güvenliği tedbirlerini dikkate alan işverenlere vergi teşviki sağlanması ve iş̧̧ilere ferdi kaza sigortası yaptırılmasının zorunlu hale getirilmesinin olduğu düşünülmektedir.

Ülkemizde 2012 yılında 6331 sayılı İş Sağlığı ve Güvenliği Kanunu (RG: T.30.06.2012, S. 28339) ile birlikte iş sağlığı ve güvenliği mevzuatında önemli gelişmeler yaşanmıştır. Ayrıca, 6552 sayılı Kanunla, 4857 sayılı İş Kanunu’nunda bazı değişiklikler yapılmıştır. Ülkemizde yasa ve yönetmeliklerde yapılan değişiklikler, risk içeren belli büyüklükteki ocakların denetimlerinin tecrübeli müfettişlerce 
yapılması büyük maden kazalarının önlenmesinde etkili rol oynamıştır. Çalışmada bazı ülkelerin aynı bölgelerinde birden fazla büyük kazanın meydana geldiği görülmektedir. $\mathrm{Bu}$ durum yasa ve yönetmeliklerin uygulanmasının ve izlenmesinin yetersiz olduğuna işaret etmektedir. Kanuni düzenlemelerdeki değişikliklerin anlamlı olması ve işçilerin sağlıklı ve güvenli bir ortamda çalışmaları için, yasal düzenlemelerin dikkate alınması ve madenlerin düzenli şekilde denetlenmesi gerekmektedir. Aksi halde madenlerde meydana gelen büyük faciaların önüne geçmek mümkün olmayacaktır.

İş sağlığı ve güvenliği önlemlerini almayan, denetimleri yapılmayan madenlerde büyük kazaların meydana gelmesi kaçınılmaz bir durumdur. Grizu patlaması, kömür tozu patlaması, su baskını, yangın, büyük göçük tehlikesi gibi riskler toplu ölümlere yol açmaktadır. Kazaları gerçekleşmeden önlemek en sağlıklı, en güvenilir ve en ucuz yöntem olduğunu da unutmadan gerekli adımların zamanında atılması oldukça önemlidir.

YAZAR KatkıLARI: Bu çalışmada yazarların katkıları eşit düzeydedir.

ÇıKAR ÇATIşMASı: Bu çalışmada herhangi bir çıkar çatışması yoktur, makale araştırma ve yayın etiğince uygundur.

Finansal Destek: Bu çalışmada herhangi bir kişi, kurum veya kuruluştan finansal destek alınmamıştır.

Eтік Комїте ONAYI: İnsan örneği veya deneysel çalışma içermediğinden etik kurulu oluru gerekmemiştir.

\section{KAYNAKÇA}

[1] Ergun, A. R. (2007). Yer Altı Maden İşletmelerinde Gaz ve Toz Patlamaları ve Önlemler. İş Sağlığı ve Güvenliği Uzmanlık Tezi, Ankara.

[2] Önder, M., Mutlu, M., Adıgüzel, E. \& Önder, S. (2015). TKİye Bağlı Açlk İşletme Kömür Madenlerindeki İş Günü Kayıplı İş Kazalarının Aşamalı Logli- neer Analiz Yöntemi ile Değerlendirilmesi. Türkiye 24. Uluslararası Madencilik Kongresi Bildiriler Kitab1, Antalya, 178-189.

[3] Tanır, F. (2009). Madenlerde İş Sağlı̆̆ı ve Güvenliğine Bakış. Maden İşletmelerinde İş Sağlığı ve Güvenliği Sempozyumu Bildiriler Kitabı, Adana, 7-8.

[4] Bilim, N., Dündar, S. \& Bilim A. (2018). Ülkemizdeki Maden Sektöründe Meydana Gelen İş Kazası ve Meslek Hastalıklarının Analizi. BEÜ Fen Bilimleri Dergisi, 7 (2), 423-432.

[5] Derin, L., Varol, N. \& Uymaz, S. (2017). Türkiye'deki Kömür Madeni Kazalarına İlişkin Değerlendirme. Journal of Resillience, 1 (1), 47-53.

[6] Güyagüler, T. (2007). İnsan Özelliklerinin Kazalara Etkisi. Maden İşletmelerinde İş Sağlığı ve Güvenliği Sempozyumu Bildiriler Kitabı, Adana, s.51-55.

[7] Bayraktar, A. (2013). Yeraltı Maden İşletmelerinde Ocak Yangınları. İş Müfettişi Yardımcılığı Etüdü, ÇSGB, Ankara, 50.

[8] Saltoğlu, S. (1975). Madenlerde Havalandırma ve Emniyet İşleri. İTÜ Maden Fak. Yayını.

[9] Ayvazoğlu, E. (1984). Maden Havalandırma ve Emniyet. İTÜ Maden Fak. Yayın No. 13.

[10] Powell, F. \& Billinge, K. (1981). The Use of Water in The Prevention of Ignitions Caused By Machine Picks. Mining Engineer, 81-85.

[11] Ökten, G. \& Yazıcı, S. (1986). Mekanize Kazıda Grizu Patlamaları. Madencilik, 25(3):17-22.

[12] Didari, V. (1985). Kömür Tozu Patlaması. Madencilik, 24(4):23-29.

[13] Mason, E. (1954). Practical Coal Mining. Virtue, 12, 787 .

[14] ÇSGB. (2011). Yeraltı ve Yerüstü Maden İşletmelerinde İş Sağlığı ve Güvenliği Rehberi. Çalışma ve Sosyal Güvenlik Bakanlığı, Ankara. 140.

[15] Arığlu, E. (2010). Tüneller. Yıldız Teknik Üniversitesi, Yapı Merkezi Ar-Ge Bölümü, İstanbul.

[16] Yaşar, S., İnal, S., Yaşar, Ö. \& Kaya, S. (2015). Geçmişten Günümüze Büyük Maden Kazaları. Bilimsel Madencilik Dergisi, 54 (2), 33-43.

[17] TMMOB. (2010). Madencilikte Yaşanan İş Kazaları Raporu. Türk Mühendis ve Mimar Odaları Birliği, Ankara. Erişim Tarihi: 20.09.2021, http:// www.maden.org.tr/resimler/ ekler/9bd3e8809c72d94_ek.pdf

[18] MSHA. (2006). Accident, Illness and Injury, and Employment Self-Extracting Files (Part 50 Data). 
Erişim tarihi: 20.09.2021, https://arlweb.msha.gov/ stats/statistics.htm

[19] CDC. (2021). Coal Mining Disasters: 1839 To Present. Erişim tarihi: 20.09.2021, https://www.cdc.gov/ niosh/mining/statistics/content/coaldisasters.html

[20] Kowalski-Trakofler, K. M., Alexander, D. A., Brnich, M. J. \& McWilliams, L. (2009). Underground Coal Mining Disasters and Fatalities - United States, 1900 -1906. In: MMWR, Vol. 57, No. 51/52, pp 13791383.

[21] Lirong, W, Zhongan, J., Weimin, C., Xiuwei, Z., Dawei, L. \& Yujing, Y. (2011). Major Accident Analysis and Prevention of Coal Mines in China From the Year of 1949 to 2009. Mining Science and Technology, 21, 693-699.

[22] Yin, W., Fu, G., Yang, C., Jiang, Z., Zhu, K. \& Gao, Y. (2017). Fatal Gas Explosion Accidents on Chinese Coal Mines and the Characteristics of Unsafe Behaviors: 2000-2014. Safety Science, 92, 173-179.

[23] Zhu, Y., Wang, D., Shao, Z., Xu, C. \& Zhu, X. (2019). A Statistical Analysis of Coalmine Fires and Explosions in China. Process Safety and Environmental Protection, 121, 357-366.

[24] Zhang, J., Xu, K., Reniers, G. \& You, G. (2020). Statistical Analysis the Characteristics of Extraordinarily Severe Coalmine Accidents (Escmas) in China From 1950 to 2018. Process Safety and Environmental Protection, 133, 332-340.

[25] Liu, X., Zhao, X. \& Zhang, Q. (2013). Study on Early Warning System of Coal and Gas Outburst. The Open Electrical and Electronic Engineering Journal, Cilt 7, 116-122.

[26] İSGK. (2012). 6331 Sayılı İş Sağlığı ve Güvenliği Kanunu. RG: T. 30.06.2012, s. 28339.

[27] Tatar, Ç. Özacar, V. (2017). Su Atımı. Temel Madencilik Bilgileri Kitabı, Mayeb Yayınları, 752-840.

[28] Yılmaz, A. (2016). Ocak Yangınlarında Kendiliğinden Yanmanın İş Sağlığı ve Güvenliği Yönünden Değerlendirilmesi. C.B.Ü. Soma MYO Tek. Bil. Dergisi, 21(1), 38-47. 